\title{
Poverty Prevention in the light of Seerah of Prophet Muhammad (peace be upon him)
}

\author{
Nabeela Falak *
}

\begin{abstract}
Poverty has become one of the major problems faced by the modern world. In the present time $50 \%$ of population is compulsive to lay a life in poverty. Poverty is not only a problem of developing countries of third world but extreme developed countries are also There are many strategies to tackle the problem of poverty like all other spheres of human life Prophet Muhammad (peace be upon him) also laid principles in the field of economics. A strategy based on Seerah of holy prophet Muhammad (peace be upon him) will be the best choice to eliminate the poverty. In this paper Prophet s contribution in eradicating of poverty is being highlighted. The main principles from the economic system given by the Holy Prophet will be presented. Examples will be coated that will show the best solution and results in prevention of poverty in any society especially from Pakistani society.
\end{abstract}

Keywords: relative and absolute, poverty, prevention, development, Seerah

\section{Introduction}

According to World Bank, "a person whose daily income is less than one or two dollar will called a poor." it is a condition where people's basic needs for food, clothing, and shelter are not being met. Poverty is generally of two types. One is 'Absolute poverty', it is synonymous with destitution and occurs when people cannot obtain adequate resources (measured in terms of calories or nutrition) to support a minimum level of physical health. Absolute poverty means about the same everywhere, and can be eradicated as demonstrated by some countries. Another type of poverty is 'Relative poverty'. It occurs when people do not enjoy a certain minimum level of living standards as determined by a government (and enjoyed by the bulk of the population) that vary

\footnotetext{
${ }^{*}$ Dr. Nabeela Falak Assistant Professor, Department of Islamic Studies, University of Lahore Sargodha Campus.nabeela.falak@ais.uol.edu.pk
} 
from country to country, sometimes within the same country. Relative poverty occurs everywhere, is said to be increasing, and may never be eradicated". ${ }^{2}$

In simple words, poverty means:" a state of a man in which he has lack of necessary resources for minimum standard of living. According to a report by World bank 2001, out of six thousands million world population one thousand million persons were compulsive to lead a life on less than one dollar daily and two million on less than two dollars daily". 3

\section{Main Problems}

A sustainable Development Policy institute, has issued a report on increasing poverty in Pakistan. According to that report more than one third of population is leading a life under poverty line. ${ }^{4}$ According to a report of World Bank, World development indicators 2008,60.2\% of population in Pakistan is living below poverty line. According to latest research of Asian Development Bank 2013, in Pakistan 29.5\% of population lives below national poverty line. In 2015 for every 1000 babies born in Pakistan, 66 die before their first birthday. ${ }^{5}$ Increase in poverty in the world is not only problem of developing countries of third world but extreme developed countries with their all recourses and efforts are looking helpless in front of poverty. In America poverty is $15 \%$ and every seventh American is living in poverty. ${ }^{6}$

Situation of Developed European countries is not different from it. International helping organization (Oxfam) has issued a report in 2013, "Oxfam analysis is based on the EU's official definition of poverty. There were 121 million people at risk of poverty in the EU representing 24.3 per cent of the population.""7

Oxfam in his report warn European countries by saying: "If left unchecked, austerity policies could put between 15 and 25 million more Europeans at risk of poverty by 2025- nearing the population of Netherlands and Austria combined. this would bring the number of people at a risk of poverty in Europe up to 146 million, over a quarter of the population warns international agency Oxfam as EU Finance Ministers in Vilnius tomorrow." 8

Poverty is such a collective problem that can destroy peace of a country at any time. Poverty dilemma is not a dilemma of present age, if we take a view of human history we will came to know that from the very begging of human history the problem of poverty and aristocracy is equally going on. to overcome the poverty, different laws and system were introduced in different countries, 
like capitalism, democracy, communism etc. In the present time every country is trying to prevent this increasing population. In 1992 United Nations declared 17 October, the World Poverty Prevention Day, the purpose to celebrate this day is to create a sense of preventing poverty especially in developing countries through seminars discussions and special programs. In spite of all these efforts, poverty is increasing day by day, and satisfactory results could not have achieved by any country including developed countries.

\section{Causes of Poverty}

Reason of unsuccessfulness in this matter is that they adjudge the reason of poverty which is infect not the cause of it. For example, educated persons and economists, they all adjudge causes of poverty are lack of recourses and wealth, changing trends in the economy of country, lack of education, high divorce rate which causes feminization of poverty, having a culture of poverty, overpopulation, epidemic diseases such as AIDS and malaria, and environmental problems such as lack of rainfall. Mostly people thought that cause of poverty is lake of recourses and wealth, so every poor and rich, to save himself from poverty, is trying to collect wealth through every legal and illegal sources. In fact, wealth and rich resources are not the solution of poverty problems. If wealth and resources are solution of the poverty, then resources of earn money and expanse in wealth are more in present age than the past.

According to my opinion the real cause of the poverty are our values, lowness of our thinking and present economic system, on that base every person is free to realization and expend of wealth. With this thinking and system man can never finish poverty. Poverty is not the name of state that a person has lack of wealth rather any person considers his present wealth insufficient for his needs and feel need of more wealth. This mental indigently is a real and big poverty. Due to this mental indigently rich and capitalists exploit the poor. As a result, economic disorder will produce in society. Poor people because of poverty become victim of many psychological puzzlement, and involve in many social crimes that cause vitiation for society and peace. For this situation national poet of Pakistan Iqbal said:

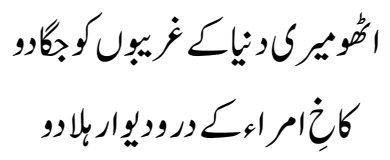




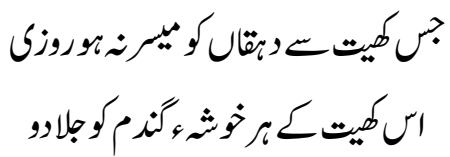

\section{Poverty Prevention}

Here we can raise a question that, is poverty really a complicated and impossible to be solved problem, that all developed countries with all their resources are unable opponent it? No! it's not. we came to know by studding the Seerah of our Holy Prophet (peace be upon him) that He not only gave solution of poverty but $\mathrm{He}$ and His believers proved this practically in their state. Holy Prophet (peace be upon him), as economists, has not given a different and new economic system but rectify the basic defects of running system, in a result poverty finis from Islamic state in some years.

When we look upon the circumstances of early time of Prophet (peace be upon him), we came to know when they migrated to Madina from Makkah, muslims were no Shelter to live and no clothes to cover themselves. Hazrat Ayesha Sadiqa (may Allah be pleased with him) narrates that Muhammad (peace be upon him) had never eat bread consecutive three days." ${ }^{9}$ That was the situation in which Holy Prophet (peace be upon him) gave a significant economic system through which poverty prevented from Islamic State in few years.

The most important principles on which Holy prophet (peace be upon him) laid the foundation to prevent poverty, are given in short:

Holy Prophet changed thinking and point of view that real wealth of a person is to be contented and rich by heart. Holy Prophet (peace be upon him) said, be contented and happy on that Allah has divided for you, you will be the richest than all others. ${ }^{10}$

Also said, Richness is not achieved by the access of wealth but real wealth is richness of heart. ${ }^{11}$

Holy Prophet (peace be upon him) gave the principle to Ummah not to be impressed by the way of living and thinking of capitalism. One should not have considered that he is all in all in earning and consuming wealth. in Islamic point of view capital and wealth is not the production of human knowledge and abilities, it's just gifted and distributed by Allah Almighty. he is not all in all in his wealth, he is Naib and in his wealth there is a share of others needy people. 
Allah Kareem said in the Holy Quran:

$$
\text { و الله فضل بعضكم على بعض فى الرزق فما اللذين فضلو ا برآدى رزقهم على ما ملكت ايمانهم فهم }
$$

فير سو آء افبنعمن الله يجحدون.

(Allah has given some of you more provision than others. Those who have been given more are unwilling to pass their provision to the servants they possess so that they become their equals. Will they deny the favor of Allah.)

There is another verse,

$$
\text { وفى اموالهم حق للسآئل و المحروم } 13 .
$$

(And sharing their possessions with the beggars and the deprived.)

Holy Prophet (peace be upon him) educated all Muslim to spend on poor and needy people and do not feel a burden to spend on them because they have a share of needy, deprived people in their earnings. He said: Try to seek my happiness in doing oblation with strength less (poor) people, because due to these people you get wealth and help. ${ }^{14}$

To prevent poverty Holy prophet divided the public into two groups, Muslim and non-Muslim. Zakat and Ushar was applied on Muslims. Jziya and Khiraj (tax for non-Muslim) was applied on non-Muslim. Holy Prophet (peace be upon him) said: No doubt Allah keep Zakat sequential for Muslim, which will be received from their rich and disburse on poor ones. ${ }^{15}$ There was no extra tax except Zakat in the period of Holy Prophet (peace be upon him). Likewise, zakat Jiziya and Kharaj was for non-Muslim. Jiziya was only received from the young and strong non-Muslim. ${ }^{16}$ Older persons were excluded from Janiya. Flexibility was shown in received Jiziya. Hazrat Umar (may Allah be pleased with him) used to check any type of injustice done in receiving Jiziya. ${ }^{17}$

Bagging is a big cause of poverty. Prophet (peace be upon him) many times discouraged imprecatory of begging, he said: When a person starts begging to others, Allah opens the door of poverty on him. ${ }^{18}$ Instead the Holy Prophet (peace be upon him) gave teaching of earning by our hands and efforts. ${ }^{19}$

Holy Prophet (peace be upon him) gave incitement to Muslim to sacrifice and to fulfill the necessities of needy people. Once on the occasion of Eid-ul-Azha he forbade to store meat because of needy and poor people and said, every person amongst you who gave Qurbani, do not store meat more than three days. ${ }^{20}$ So the companion of the holy Prophet (peace be upon him) did accordingly and instead of storing meat, they distributed it in needy persons. 
Prophet (peace be upon him) taught to give extra things to needy and deprived people. In the time of drought Hazrat Umar (may Allah be pleased with him) said: "meal of one person can save two persons to die."20

To prevent people from poverty Holy Prophet (peace be upon him) gave barren lands to people and said, he who cultivated barren land, he is the owner of it. ${ }^{21}$ That is why holy Prophet (peace be upon him) gave some land to the people of tribe Mezina, which they did not cultivated but another tribe cultivated that land. After sometime both tribes quarreled on this land, and matter went to the caliph Umar (may Allah be pleased with him). Caliph Umar (may Allah be pleased with him) did according to the Hadith of Holy Prophet (peace be upon him).

Corruption, usury, immixing, storing things and illegal earning are also a major causes of poverty in present time. Holy Prophet (peace be upon him) permitted only Halal (legal) sources of earning; He declared illegal earning a bad and worst action. Therefore, even the charity from illegal earning is not accepted. ${ }^{23}$ It is the responsibility of Muslim State to take care of needs of public. As the Holy Prophet said, ruler is the guardian of every person who have no guardian. ${ }^{24}$ This hadith expressively clear that unemployed and needy people are the responsibility of the Islamic State and they a will be answerable for it. It was the effect of teaching of the holy Prophet (peace be upon him) that Khulafa-eRashideen had kept in mind that responsibility. That is why Hazrat Umar (may Allah be pleased with him) said, if a baby of goat will die with hunger on the bank of river Furaat, I fear that Allah will enquire to me about it. ${ }^{25}$

Above mentioned main points are some of that golden principles on which Holy Prophet (peace be upon him) not only kept the base of Islamic economy, but also predicted that very soon you will not find any single poor or needy person in this Islamic state. Prophet (peace be upon him) said to Hazrat Addi bin Hatim (may Allah be pleased with him): "If you would remain alive, you will surely see a person with handful gold and silver for charity, in search of any needy person, but he would not find any person who take this gold and silver from him." $" 26$

The eye of sky had seen that prospect when that prediction came true in the period of Hazrat Umar bin Abdul Aziz (may Allah be pleased with him) with a great state area of 57, 91,000 square miles, when the situation of prosperity of public was that people come with a lot of wealth to Khalifa for charity, but no 
person was found who deserve that charity and he returned back with his wealth. ${ }^{27}$

\section{Conclusion}

It is evident that a system given by Holy Prophet (peace be upon him) is great and golden economic system. Being Muslim it is our belief that even today we follow the teaching of Prophet (peace be upon him), we will emancipate the gigantic of poverty from Pakistan and any country. This is the only way and system through which we can prevent poverty from any society and country, otherwise how much we will try and introduce latest economic system of the world, poverty cannot be prevented from any country.

\section{References}

1. http://data.world bank.orgindicator/SI.POV.2DAY

2. http:/www.businessdictionary.com/definition.condition.html

3. http:/ur.wikipedia, org/wiki/\%D8\%BA\%D8\%BI\%D8\%AB\%D8\%AA

4. http://tribune.com.pk/story/67805/sdpi-report-58-7m-pakistanis-livingbelow-poverty-line/

5. http:/www.adb.org/countries/Pakistan/poverty

6. http://www.urduvou.com/content/us-poverty/1751792.html

7. http://www.oxfam.org/en/eu/pressroom/pressrelease/2013-09-12/25million-more-europeans-risk-poverty-2025-if-austerity-drags-on

8. http://www.oxfam.org/en/eu/pressroom/pressrelease/2013-09-12/25million-more-europeans-risk-poverty-2025-if-austerity-drags-on

9. Muhammad ibn Ismail Al Bukhari. Sahih Al Bukhari. hadith no. 6454

10. Muhammad ibn Isa Al Tirmizi. Jami Al Tirmazi. Kitab al Zuhad, Hadith no. 2305

11. Muhammad ibn Ismail Al Bukhari. Sahih Al Bukhari. Kitab Riqaq, Hadith no. 6446

12. Al Quran. Surah Nahl, verse 71

13. Al Quran. Surah Zariyat, verse 19

14. Muhammad ibn Isa Al Tirmizi. Jami Al Tirmazi. Kitab Zohad. Hadith no. 1702

15. Muhammad ibn Ismail Al Bukhari. Sahih Al Bukhari. Kitab al zakat, Hadith no. 1496

16. Abu Daud Sulayman ibn al Ashath. Sunan Abu Dawood. Kitab al Kharaj, Hadith no.3040 
17. Abu Yousaf, Kitabul Kharaj. Beirut: Dare Almarifa. 1989, p.37

18. Muhammad ibn Isa Al Tirmizi. Jami Al Tirmazi. Kitab al Zuhad, Hadith no. 2325

19. Muhammad ibn Ismail Al Bukhari. Sahih Al Bukhari. Kitab al Bayyuo, Hadith no.2072

20. Ibid. Kitab al Azahi, Hadith no.5569

21. Ibid. Kitab al Adab, Hadith no. 562

22. Abu Daud Sulayman ibn al Ashath. Sunan Abu Dawood. Kitab al Kharaj, Hadith no.3075

23. Abne Habban. Sahih Abne Habban, 11/8 Beirut: arisala.1993

24. Abu Daud Sulayman ibn al Ashath. Sunan Abu Dawood. Kitab al Nikah, Hadith no. 2085

25. Abne Saad. Tabaqat Abne Saad. Beirut: Daru Sadir. p.305/3

26. Muhammad ibn Ismail Al Bukhari. Sahih Al Bukhari. Kitab al Manaqib, Hadith no.3595

27. Behqi. Adalial e Nabaviya. Beirut: Dar Kutab Alilmiya1988, p.493/6 